\title{
İstanbul'un Bazı Semtlerinde Yaşayan Bireylerin Gıda Güvenliği ve Hijyen Konusundaki Bilgi ve Tutumları
}

\author{
Seda OĞUR ${ }^{* 1}$, Nuray ERKAN² \\ ${ }^{I}$ Bitlis Eren Üniversitesi, Mühendislik-Mimarllk Fakültesi, Gıda Mühendisliği Bölümü, Bitlis

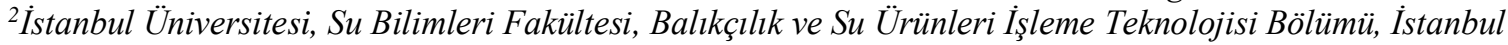

\begin{abstract}
Öz
Bu araştırmada İstanbul'un bazı semtlerinde ikamet eden, farklı eğitim seviyesine sahip katılımcıların gıda güvenliği ve hijyen konusundaki bilgi ve tutumlarının belirlenmesi amaçlanmıştır. 1 Şubat- 30 Haziran 2014 tarihleri arasında yürütülen çalışmada, gelişigüzel örnekleme yöntemiyle seçilen 596 katılımcının cinsiyet ve eğitim durumlarıyla gıda güvenliği ve hijyen ile ilgili en önemli kavramlar, donmuş et ürünü alma ve çözdürme, el yıkama, mutfakta yemek hazırlama, pişirme ve saklama aşamalarında dikkat edilmesi gereken parametreler konusundaki bilgi düzeylerini ve alışkanlıklarını değerlendirmeyi sağlayacak şekilde tasarlanmış, 23 adet sorudan oluşan bir anket formu uygulanmıştır. Araştırma verilerinin değerlendirilmesinde, IBM SPSS $21{ }^{\circledR}$ programındaki sıklık ve Pearson ki-kare testleri uygulanmış, $p<0,05$ düzeyi istatistiksel açıdan anlamlı kabul edilmiş̧ir. "Pişirmek üzere aldığınız donmuş et ürününü (kırmızı et, tavuk, balık, karides veya kalamarı) çözündürdünüz, ancak pişiremediniz, tekrar dondurur musunuz?", "yemek hazırlığına başlamadan önce el yıkamak neden önemlidir?", "mutfakta yemek hazırlığı ve pişirmesi sırasında aşağıdakilerden hangilerini kullanırsınız?", "mutfakta yemek hazırlığı sırasında kullanılan araç, gereç, alet vb. temizliğini ne sıklıkla yaparsınız?", "pişen et, tavuk ya da balığın iç sıcaklı̆̆ı aşağıdaki şıklardan hangisi olmalıdır?" ve "yeniden 1sıtma işlemine tabi tutulacak et ve balık yemekleri en az kaç dereceye kadar 1sitılmalıdır?" sorusu dışında, katılımcıların sorulara verdikleri cevaplar ile cinsiyetleri arasında anlamlı farkın olmadığı $(p>0,05)$, katılımcıların eğitim durumları ile "hijyen ne demektir?", "aşağıdakilerden hangisi gıda zehirlenmelerine sebep olur?", "mutfakta mikroorganizmaların yayılmasında hangisi etkili olur?", "yıkanmış ellerin kurulanmasında aşağıdakilerden hangisini tercih edersiniz?", "mutfakta yemek hazırlığı ve pişirmesi sırasında aşağıdakilerden hangilerini kullanırsınız?", "pişen et, tavuk ya da balığın iç sıcaklığı aşă̆ıdaki şıklardan hangisi olmalıdır?" sorularına verdikleri yanıtlar arasında ise anlamlı fark $(p<0,05)$ olduğu bulunmuştur. Gıda güvenliği ve hijyen ile ilgili olarak en önemli olduğunu düşündüğümüz bilgiler ve uygulamalar konusunda; katılımcıların doğru bilgi veya doğru alışkanlık sahibi olmaları ile eğitim seviyesi arasındaki ilişkinin beklenildiği şekilde anlamlı olmadığı gözlemlenmiştir.
\end{abstract}

Anahtar kelimeler: Gida güvenliği, hijyen, bilgi, tutum.

\section{Knowledge and Attitudes of Individuals Living in Some Districts of Istanbul about Food Safety and Hygiene}

\begin{abstract}
In this research has been aimed to determine knowledge and attitudes of peoples with different education levels living in the some districts of Istanbul about food safety and hygiene. In the study conducted between 1 February and 30 June 2017, a questionnaire consisting of informations related to gender, education level and 23 questions, designed to evaluation of their knowledge level and their habits about the most important concepts related to food safety and hygiene, some parameters should be considered in stages, such as buying and thawing frozen meat products, hand washing and meal preparing in kitchen, cooking and storing of meal has been applied to 596 individuals, selected by haphazard sampling method. In evaluation of research data has been applicated frequency and Pearson chi-square tests the IBM SPSS $21 \circledR$ program, $p<0,05$ level has been accepted significantly as statistical. It has been found that except of "did you defrost the frozen meat product (red meat, chicken, fish, shrimp or calamari) you bought for cooking, but you cooking it, would you freeze it again?", "why is important to wash hands before starting the meal preparation?", "which of the following are used during the meal preparation and cooking in the kitchen?", "how often do you do the cleaning of equipment, tools, etc. used during the meal
\end{abstract}

*Sorumlu yazar: sdogur@beu.edu.tr

Geliş Tarihi: 02.10.2018, Kabul Tarihi: 08.01.2019 
preparation in the kitchen?", "whichever of the following options should be the internal temperature of cooked meat, chicken or fish?" and "how much degree should be heated the meat and fish meals would be reheated?" question, the difference was insignificant $(p>0,05)$ between the answers of participants given to questions and gender, the difference was significant $(p<0,05)$ between education level of participants and their answers given to "what is meant hygiene", "which of the following causes food poisoning", "which would be effective in the spread of microorganisms in the kitchen", "which of the following would you prefer in drying the washed hands?", "which of the following do you use during meal preparation and cooking in the kitchen?", "whichever of the following options should be the internal temperature of cooked meat, chicken or fish?" questions. In terms of information and practices that we think are the most important in terms of food safety and hygiene; it has been observed that relationship between education level and correct knowledge or right habit of participants was not significant as expected.

Keywords: Food safety, hygiene, knowledge, attitude.

\section{Giriş}

Gıda güvenliği kavramı gıdaların amaçlanan kullanımına uygun olarak hazırlanması ve tüketildiği zaman tüketen kişilere herhangi bir zararının olmaması anlamında kullanılmaktadır. Daha geniş değerlendirmek gerekirse gıda ürünlerinin her türlü fiziksel, kimyasal ve biyolojik tehlikeleri ortadan kaldıracak şekilde hazırlanması, işlenmesi, depolanması ve tüketiciye ulaşmasını ifade eden bilimsel bir sistemsel döngüdür. $\mathrm{Bu}$ anlamda; her çeşit kontaminasyona ve bozulmaya sebep olan etkenin bertaraf edilmesiyle tüketime uygun hale getirilmiş gıda ürünü, güvenli gıda olarak vasıflandırılmaktadır [1, 2].

Hijyen denildiği zaman genellikle temizlik kavramı anlaşılmaktadır. Ancak her bireyin temizlik anlayışı ve uygulama şekli farklılık göstermektedir. Hijyen-temizlik kavramı içinde kişisel temizlik, el ve vücut temizliği en başta gelmektedir. Gıda işletmelerinde ve satış yerlerinde çalıştırılan personelin bu kavramları doğru algılaması ve yorumlaması oldukça önem arz etmektedir [3, 4].

Gıda üretim ve satış yerlerinde her zaman hijyen standartlarına uygun üretimin yapılması ve bu ürünlerin güvenli bir şekilde tüketicilere ulaşması isteniyorsa sürekliliği sağlanan gida güvenliği kontrol sistemi mutlaka kurulmalıdır [1,3].

Gıda kaynaklı hastalık ve zehirlenmelerin çoğu insan kaynaklı mikroorganizmalar aracılığıyla olmakta ve bu durumu en çok gıda hazırlamada çalışan bireylerin hijyen ve temizlik uygulamaları etkilemektedir. Aynı olgu evde hazırlanan yemekler için de geçerlidir. Bireyler yemeklerini hazırlarken uymaları gereken hijyen-temizlik ve gıda güvenliği ile ilgili kurallar ve bu kuralları etkileyecek, dikkat etmeleri gereken hususlar konusunda doğru bilgiye sahip değillerse gıda kaynaklı hastalıklara maruz kalmaları kaçınılmazdır [1-3].

Günümüz koşullarında, büyük şehirlerdeki yoğun ve hızlı yaşam akışı içinde, sağlıklı bir hayat sürdürebilmek için tüketicilerin bu konularda doğru bilgi edinmeleri ve bunları her zaman doğru şekilde uygulamaya özen göstermeleri büyük öneme sahiptir. Çocukluk çağından itibaren bu konulardaki bilgi, kural ve uygulamalara eğitim sistemi içinde bilgilendirici seminerler veya fen, sağlı veya biyoloji ders müfredatı içinde yer verilmeli, her alanda olduğu gibi bu konularda da eğitimin önemi unutulmamalıdır [2, 4].

$\mathrm{Bu}$ çalışmada İstanbul'un bazı semtlerinde ikamet eden, farklı eğitim seviyesine sahip katılımcıların gıda güvenliği ve hijyen konusundaki bilgi ve tutumları eğitim düzeyi ve cinsiyet değişkenine göre belirlenmeye çalışılmıştır.

\section{Materyal ve Metot}

1 Şubat-30 Haziran 2014 tarihleri arasında yürütülen çalışmanın evrenini, İstanbul'un Fatih, Bakırköy, Kadıköy ve Şişli semtlerinde ikamet eden 18 yaş üzeri bireyler oluşturmuştur. Gelişigüzel örnekleme yöntemiyle, çalışma süresi içerinde ulaşılabilen 596 adet gönüllü katılımcıya İstanbul Üniversitesi Su Bilimleri Fakültesi 4. Sınıf öğrencileri tarafından çalışmanın amacı ve kapsamı anlatılarak; kendileri bilgilendirildikten sonra onayları alınmış ve cinsiyet ve eğitim durumu bilgileri ile 23 adet sorudan oluşan bir anket formu yüz yüze görüşülerek uygulanmıştır. Bu çalışma, İstanbul Üniversitesi Su Bilimleri Fakültesi İşleme Teknolojisi Anabilim Dalı tarafindan yürütülmüştür.

Anket formunda, 6 adet; katılımcı genel gıda güvenliği ve hijyen ile ilgili en önemli kavramlar, 3 adet; donmuş et ürünü alma ve çözdürme, 4 adet; el yıkama, 6 adet; mutfakta yemek hazırlama, 4 adet; 
pişirme ve saklama aşamalarında dikkat edilmesi gereken parametreler konusundaki bilgi ve tutumlarını değerlendirmeyi sağlayacak şekilde toplam 23 adet soru bulunmaktadır. Anket formlarından elde edilen araştırma verilerinin değerlendirilmesinde IBM SPSS 21® programındaki siklık ve Pearson ki-kare testleri uygulanmuş, $p<0,05$ düzeyi istatistiksel açıdan anlamlı kabul edilmiştir.

\section{Bulgular ve Tartışma}

Katılımcıların 362'sinin $(\% 60,7)$ kadın, 234'ünün $(\% 39,3)$ erkek olduğu görülmüştür. Ankete katılanların 47'sinin $(\% 7,9)$ ilkögretim mezunu, 137'sinin $(\% 23,0)$ lise mezunu, 371'inin $(\% 61,2)$ lisans mezunu, 41 'inin $(\% 6,9)$ lisansüstü mezunu olduğu belirlenmiştir.

Tablo 1'de katılımcıların gıda güvenliği ve hijyen ile ilgili en önemli kavramlara ait bilgi ve tutumlarını belirten dağılım verilmiştir.

Tablo 1. Katılımcıların gıda güvenliği ve hijyen ile ilgili en önemli kavramlara ait bilgi ve tutumlarını belirten dağılım

\begin{tabular}{|c|c|c|}
\hline 1. Hijyen ne demektir? & Sayı & $\%$ \\
\hline a) Görünen kirin uzaklaştırılması (temizlik) & 16 & 2,7 \\
\hline b) Görünmeyen kirin (hastalık yapıcı) uzaklaştırılması (dezenfekte etmek) & 50 & 8,4 \\
\hline c) İkisi birden* & 530 & 88,9 \\
\hline Toplam & 596 & 100,0 \\
\hline \multicolumn{3}{|l|}{ 2. Hangisi gida zehirlenmelerine sebep olur? } \\
\hline a) Gidaları bozan bakteriler & 271 & 45,4 \\
\hline b) Patojen (hastalık yapıcı) bakteriler* & 234 & 39,3 \\
\hline c) Küfler & 91 & 15,3 \\
\hline Toplam & 596 & 100,0 \\
\hline \multicolumn{3}{|l|}{ 3. Mutfakta mikroorganizmaların yayılmasında hangisi etkili olur? } \\
\hline a) Eller & 16 & 2,7 \\
\hline b) Kesme tahtaları & 10 & 1,7 \\
\hline c) Sünger ve bezler & 24 & 4,0 \\
\hline d) Mutfak araç ve gereçleri & 7 & 1,2 \\
\hline e) Çöp kovaları & 80 & 13,4 \\
\hline f) Hepsi* & 459 & 77,0 \\
\hline Toplam & 596 & 100,0 \\
\hline \multicolumn{3}{|l|}{ 4. Hangisi çok çabuk bozulabilir gıdalardan değildir? } \\
\hline a) Biftek & 12 & 2,0 \\
\hline b) Balık & 25 & 4,2 \\
\hline c) Tavuk & 14 & 2,3 \\
\hline d) Bisküvi* & 543 & 91,1 \\
\hline e) Bilmiyorum & 2 & 0,3 \\
\hline Toplam & 596 & 100,0 \\
\hline \multicolumn{3}{|l|}{ 5. Uygun buzdolabı sıcaklığı aşağıdakilerden hangisidir? } \\
\hline a) $15^{\circ} \mathrm{C}$ & 43 & 7,2 \\
\hline b) $10^{\circ} \mathrm{C}$ & 105 & 17,6 \\
\hline c) $4{ }^{\circ} \mathrm{C}^{*}$ & 433 & 72,7 \\
\hline d) $20^{\circ} \mathrm{C}$ & 11 & 1,8 \\
\hline e) Bilmiyorum & 4 & 0,7 \\
\hline Toplam & 596 & 100,0 \\
\hline \multicolumn{3}{|l|}{$\begin{array}{l}\text { 6. Buzdolabında soğutma işlemi gıdanın içinde bulunan tehlikeli bakterilerin } \\
\text { hepsini öldürür mü? }\end{array}$} \\
\hline a) Daha çok çoğalmalarını sağlar & 8 & 1,3 \\
\hline b) Soğuk dolap bakterileri etkilemez & 35 & 5,9 \\
\hline c) Hepsini öldürür & 42 & 7,0 \\
\hline d) Hayır, fakat gıdayı soğukta tutarak bakterilerin çoğalmalarını önler* & 511 & 85,7 \\
\hline Toplam & 596 & 100,0 \\
\hline
\end{tabular}

*Anket sorusunun doğru cevabıdır. 
Katılımcıların \%2,7'si hijyenin görünen kirin uzaklaştırılması (temizlik), \%8,4’ü görünmeyen kirin (hastalık yapıcı) uzaklaştırılması (dezenfekte etmek), \%88,9'u ise doğru yanıt olan her ikisinin birden yapılması olduğunu ifade etmiştir.

Katılımcıların \%45,4’ü gıda zehirlenmelerine gıdaları bozan bakterilerin, \%39,3’ü patojen (hastalık yapıc1) bakterilerin, \%15,3’ü küflerin sebep olduğunu belirtmiştir (Tablo 1).

Katılımeılara mutfakta mikroorganizmaların yayılmasında hangisi etkili olur diye sorulduğunda; \%2,7'si eller, \%1,7'si kesme tahtaları, \%4,0'ü sünger ve bezler, \%1,2'si mutfak araç ve gereçleri, \%13,4'ü çöp kovaları, \%77,0'si ise hepsi cevabını vermiştir (Tablo 1).

Katılımcıların \%2,0'si bifteğin, \%4,2'si balığın, \%2,3'ü tavuğun, \%91,1'i ise doğru yanıtı işaretleyerek; bisküvinin çok çabuk bozulabilir gıdalardan olmadığını bildirmiştir (Tablo 1).

Katılımciların \%7,2'si uygun buzdolabı sicaklığının $15{ }^{\circ} \mathrm{C}$, \%17,6's1 $10{ }^{\circ} \mathrm{C}, \% 1,8$ 'i $20{ }^{\circ} \mathrm{C}$ olduğunu belirtirken; \%0,7'si "bilmiyorum" şeklinde yanıtlamıştır. Doğru yanıt olan "4 ${ }^{\circ} \mathrm{C}$ " yanıtını işaretleyenlerin oranı ise \%72,7 olmuştur (Tablo 1).

"Buzdolabında soğutma işlemi gıdanın içinde bulunan tehlikeli bakterilerin hepsini öldürür mü?” sorusuna ankete katılan katılımcıların \%1,3'ünün "daha çok çoğalmalarını sağlar”, \%5,9'unun “soğuk dolap bakterileri etkilemez", \%7,0'sinin "hepsini öldürür”, \%85,7'sinin ise doğru yanıt olan; "hayır, fakat gıdayı soğukta tutarak bakterilerin çoğalmalarını önler" cevabını verdiği görülmüştür (Tablo 1).

Katılımcıların genel gıda güvenliği ve hijyen ile ilgili en önemli kavramlardan olan; hijyenin ne demek olduğu, mutfakta mikroorganizmaların yayılmasında hangi araçların etkili olduğu, hangi gıdaların çok çabuk bozulabilir gıdalardan olduğu, uygun buzdolabı sıcaklığının kaç derece olduğu ve buzdolabında soğutma işleminin gıdanın içinde bulunan tehlikeli bakterilerin hepsini öldürüp öldürmediği konularındaki bilgi ve tutumlarının olumlu olduğu görülmüştür. Ancak, katılımcıların $\% 60,7$ 'sinin gida zehirlenmelerine hangi mikroorganizmaların sebep olduğu konusunda doğru bilgiye sahip olmadığ 1 saptanmıştır (Tablo 1).

Askarian vd. [5]; İran'daki 31 hastanede çalışan yemek servis elemanlarının bakterilerin tanınması, soğuk yiyeceklerin buzdolabında muhafaza dereceleri ve sıcak yiyeceklerin servis alanındaki muhafaza dereceleri ile ilgili olarak sahip oldukları bilginin belli düzeyde olduğunun bulunması bizim çalışmamızla uyuşmaktadır.

ABD Hastalık Kontrol ve Önleme Merkezi gidaları uygun olmayan bir sıcaklıkta muhafaza etmenin ya da bekletmenin gıda kaynaklı hastalıklarına sebep olma oranını \%37 olarak belirtmiştir. $\mathrm{Bu}$ sebeple gıdalar mikrobiyal gelişmenin nispeten ağır seyrettiği $5{ }^{\circ} \mathrm{C}$ 'nin altındaki bir soğutucuda muhafaza edilmelidir [6].

Koçoğlu vd. [7]'nin çalışmasında gıdaların hazırlanması ve saklanması aşamasındaki uyulması gereken hijyen kuralları ile ilgili sorulara verilen yanttların eğitim seviyesi ile uyum göstermediği anlaşılmıştır. Personelin gıda hijyeni ve sanitasyonu açısından önem taşıyan konulardaki bilgi seviyesinin yeterli düzeyde olmadığı, uygulamalarda yaşanan problemlerin bertaraf edilmesi için hizmet içi eğitimler ile eğitilmeleri gerektiği belirtilmiştir. Bizim çalışmamızda katılımcılara yöneltilen 23 sorudan 12'sine verilen cevaplar ile katılımcıların eğitim durumları arasında anlamlı fark olmadığının $(p>0,05)$ ortaya çıkması Koçoğlu vd. [7]'nin çalışmasını doğrulamıştır.

Uzunöz vd., [8] tarafından yürütülen araştırmada kırsal alanda hayatını sürdüren bayanların gıda güvenliği konusunda sahip oldukları bilinç düzeyleri ile eğitim seviyeleri arasında bizim çalışmamızdan farklı olarak yüksek derecede bir ilişki belirlenmiştir.

Şanlıer vd. [9]'nin otel personelleri ile yürüttükleri çalışmada personelin eğitim düzeyleri ile genel hijyen puanları ve diğer hijyen konularındaki (mutfak ve ekipman, personel ve gida hijyeni) puanları arasında anlamlı fark $(p<0,05)$ bulunması ve Ünüsan [10]'ın yürüttüğü araştırmada da eğitim düzeyinin artmasıyla gıda güvenliği bilgi puanının geliştiğinin $(p<0,01)$ görülmesi bizim çalışmamızla uyuşmamaktadır.

Memiş Kocaman ve Şanlıer [11]'in araştırmasında öğretmenlerin sadece \%29,9'unun gida güvenliği hakkında yeterli bilgiye sahip olması bizim çalışmamızla benzer bulunmuştur.

Katılımcıların donmuş et alma ve çözdürme ile ilgili kavramlara ait bilgi ve tutumlarını belirten dağ 1 lım Tablo 2'de verilmiştir.

Paketli halde satılan donmuş et ürünü alırken ankete katılan katılımcıların \%2,0'si "paketin sağlamlığına", \%15,8’i "son kullanma tarihine", $\% 2,5$ 'i “ürünün görüntüsüne” dikkat ettiğini belirtirken; doğru yanıt olan "hepsi" cevabını verenlerin oranı \% 79,7 olmuştur (Tablo 2). 
Katılımcıların \%47,5'i donmuş et ürününü oda sıcaklığında bekleterek, \%31,5'i buzdolabında bekleterek, \%20,6'sı su içerisinde tutarak çözdürdügünü belirtirken; \%0,3'ü konu hakkında fikri olmadığını söylemiştir (Tablo 2). Bu uygulamada doğru olan donmuş et ürününün buzdolabında bekleterek çözdürülmesidir.

Tablo 2. Katılımcıların donmuş et ürünü alma ve çözdürme ile ilgili kavramlara ait bilgi ve tutumlarını belirten dağılım

\begin{tabular}{|c|c|c|}
\hline $\begin{array}{l}\text { 7. Paketli halde satılan donmuş et ürünü (kırmızı et, tavuk, balık, karides veya } \\
\text { kalamar) alırken en çok nelere dikkat edilmelidir? }\end{array}$ & Sayı & $\%$ \\
\hline a) Paketin sağlamlığına & 12 & 2,0 \\
\hline b) Son kullanma tarihine & 94 & 15,8 \\
\hline c) Ürünün görüntüsüne & 15 & 2,5 \\
\hline d) Hepsine* & 475 & 79,7 \\
\hline Toplam & 596 & 100,0 \\
\hline \multicolumn{3}{|l|}{$\begin{array}{l}\text { 8. Donmuş et ürünü (kırmızı et, tavuk, balık, karides veya kalamar) temin } \\
\text { edildiyse pişirmeden önce nasıl çözülmesini sağlarsınız? }\end{array}$} \\
\hline a) Oda sicaklığında bekleterek & 283 & 47,5 \\
\hline b) Buzdolabinda bekleterek* & 188 & 31,5 \\
\hline c) Su içerisinde tutarak & 123 & 20,6 \\
\hline d) Fikrim yok & 2 & 0,3 \\
\hline Toplam & 596 & 100,0 \\
\hline \multicolumn{3}{|l|}{$\begin{array}{l}\text { 9. Pişirmek üzere aldığınız donmuş et ürününü (kırmızı et, tavuk, balık, karides } \\
\text { veya kalamarı) çözündürdünüz, ancak pişiremediniz, tekrar dondurur musunuz? }\end{array}$} \\
\hline a) Evet & 99 & 16,6 \\
\hline b) Hayır* & 497 & 83,4 \\
\hline Toplam & 596 & 100,0 \\
\hline
\end{tabular}

*Anket sorusunun doğru cevabıdır.

Kişilere çözündürdükleri, ancak pişiremedikleri et ürünlerini tekrar dondurup dondurmadıkları sorulduğunda; \%16,6's1 tekrar dondurduğunu, \%83,4'ü ise doğru yanıtı işaretleyerek; tekrar dondurmadığını dile getirmiştir (Tablo 2).

Katılımcıların donmuş et ürünü (kırmızı et, tavuk, balık, karides veya kalamar) alma ve çözdürme ile ilgili kavramlara ait bilgi ve tutumlarını ortaya koyan; paketli halde satılan donmuş et ürünü alırken en çok nelere dikkat edilmesi gerektiği ve pişirmek üzere alınan donmuş et ürününü çözündürdükten sonra tekrar dondurulup dondurulmayacağı konularındaki bilgi ve tutumlarının büyük oranda doğru olduğu tespit edilmiştir. Ancak, katılımcıların \%68,1'inin donmuş et ürünü temin edildiyse pişirmeden önce nasıl çözülmesi gerektiği konusunda yanlış uygulamalarda (oda sicaklığında bekletme ve su içerisinde tutma) bulunduğu görülmüştür (Tablo 2).

Sağlam vd. [13]'nin çalışmasında tüketicilerin \%86'sının ürünün son kullanma tarihine dikkat ettikleri belirlenmiştir. Yapılan başka bir araştırmada ise gıda ürününü satın alırken son kullanma tarihine bakmayan tüketicilerin \%39,6 oranında olduğu bulunmuştur [13]. Bizim çalışmamızda bu çalışmalardan farklı olarak katılımcıların \%79,5'i donmuş et ürünü (kırmızı et, tavuk, balık, karides veya kalamar) alırken; paketin sağlamlığı, son kullanma tarihi ve ürünün görüntüsü parametrelerinden hepsine baktığını ifade etmişlerdir (Tablo 2).

Lynch vd. [14] tarafından Oklahoma şehrindeki lokantalarda çalışan işçilerin \%91,7'sinin dondurulmuş et ürünlerini buzdolabında çözündürdükleri belirlenmiştir. Bizim çalışmamızda ise katılımcıların \%47,5'inin dondurulmuş et ürünlerini çözdürme işlemini oda sıcaklığında bekleterek yaptığını, sadece \%31,5'inin buzdolabında bekleterek yaptığını ifade etmesi bu çalışmayla uyuşmamaktadır.

Askarian vd. [5] buzu çözülen gıdalar yalnızca bir defa tekrar dondurabilir seçeneğini belirtenlerin \%52,9 oranında olduğunu bulmuştur. Bizim çalışmamızda bu çalışmadan oldukça farklı olarak katılımcıların \%83,4'ü donmuş et ürününü (kırmızı et, tavuk, balık, karides veya kalamarı) tekrar dondurmadığını belirtmiştir (Tablo 2).

Donmuş ürünlerin çözdürülmesi bir gece öncesinden buzdolabında $\left(\leq 5{ }^{\circ} \mathrm{C}\right.$ ' de) bekleterek, mikrodalga firında isıtarak ya da akmakta olan soğuk suyun altında tutarak gerçekleştirilmelidir. Çözündürülmüş gıdalar hemen pişirilerek tüketilmeli, tüketilmeyecek ise tekrar dondurulabileceği düşünülmemelidir. Gıdalarda çoğalarak gıda kaynaklı hastalıklara neden olan patojen bakterilerin 
gelişebileceği sıcaklık aralı̆̆ $5-57{ }^{\circ} \mathrm{C}$ olduğu için özellikle bu açıdan potansiyele sahip olan gıda ürünleri, bu sıcaklık aralıklarında uzun süre tutulmamalı, çözdürülmemeli ve gıda hazırlanırken mümkün olduğunca hızlı çalışılmalıdır [6].

Katılımcıların el yıkama konusundaki bilgi ve tutumlarını belirten dağılım Tablo 3'te sunulmuştur.

Tablo 3. Katılımcıların el yıkama konusundaki bilgi ve tutumlarını belirten dağılım

\begin{tabular}{|l|c|c|}
\hline 10. Eller ne zaman yıkanmalıdır? & Sayı & \% \\
\hline a) Yemek hazırlığına başlamadan önce & 37 & 6,2 \\
\hline b) Pişmemiş gıdalara (sebze, meyve, et, tavuk, balık vb.,) temastan sonra & 0 & 0,0 \\
\hline c) Yemek yemeden önce ve sonra & 18 & 3,0 \\
\hline d) Tuvalete girerken ve çıktıktan sonra & 12 & 2,0 \\
\hline e) Çöp ile temastan sonra & 5 & 0,8 \\
\hline f) Hapşırma, öksürme gibi işlemlerden sonra & 2 & 0,3 \\
\hline g) Hepsi* & 518 & 86,9 \\
\hline h) Bilmiyorum & 3 & 0,5 \\
\hline Toplam & 596 & 100,0 \\
\hline 11. Yemek hazırlığına başlamadan hemen önce elleri yıkamak neden önemlidir? & & \\
\hline a) Genel bir kural olarak belirtildiği için & 11 & 1,8 \\
\hline b) Ellerdeki mikroorganizmaların gıdalara bulaşmaması için* & 452 & 75,8 \\
\hline c) Gıdalardaki mikropların ellere bulaşmaması için & 26 & 4,3 \\
\hline d) Ellerin temiz olması için & 107 & 18,0 \\
\hline Toplam & 596 & 100,0 \\
\hline 12. Hangisi el yıkama işleminde kullanılan malzemedir? & & \\
\hline a) Tırnak firçası & 16 & 2,7 \\
\hline b) Sicak su & 107 & 17,9 \\
\hline c) Dezenfektanlı el jeli & 180 & 30,2 \\
\hline d) Hepsi* & 293 & 49,2 \\
\hline Toplam & 596 & 100,0 \\
\hline 13. Yıkanmııs ellerin kurulanmasında aşağıdakilerden hangisini tercih edersiniz? & & \\
\hline a) Mutfak önlüğüme kurularım & 16 & 2,7 \\
\hline b) Kağıt havlu kullanırım* & 402 & 67,4 \\
\hline c) Normal mutfak havlusunu tercih ederim & 178 & 29,9 \\
\hline Toplam & 596 & 100,0 \\
\hline An
\end{tabular}

*Anket sorusunun doğru cevabıdır.

Katılımcıların \%6,2'si ellerin yemek hazırlığına başlamadan önce, \%3,0'ü yemek yemeden önce ve sonra, \%2,0'si tuvalete gitmeden önce ve sonra, \%0,8'i çöp ile temastan sonra, $\% 0,3$ 'ü hapşırma, öksürme gibi işlemlerden sonra yıkanması gerektiğini belirtirken; doğru yanıt olan "hepsi" seçeneğini işaretleyenlerin oranı \% 86,9 olmuştur. Üç katılımcı ise bu soruya "bilmiyorum" şeklinde yanıt vermiştir (Tablo 3).

"Yemek hazırlığına başlamadan hemen önce elleri yıkamak neden önemlidir?" sorusuna \%1,8'i "genel bir kural olarak belirtildiği için", \%75,8'i doğru yanıt olan; "ellerdeki mikroorganizmaların gıdalara bulaşmaması için”, \%4,3'ü "gıdalardaki mikroorganizmaların ellere bulaşmaması için", $\% 18,0$ 'i "ellerin temiz olması için" cevabını vermiştir (Tablo 3).

El yıkama işleminde kullanılan malzeme olarak; \%2,7'si “tırnak firçası", \%17,9'u "sıcak su", \%30,2'si “dezenfektanlı el jeli", \%49,2'si doğru yanıt olan "hepsi” seçeneğini işaretlemiştir (Tablo 3).

Katılımcıların \%2,7'si ellerini yıkadıktan sonra mutfak önlüğüne kuruladığını, \%67,4’ü doğru seçeneği işaretleyerek; kağıt havlu kullandığını, \%29,9'u normal mutfak havlusunu tercih ettiğini ifade etmiştir (Tablo 3).

Katılımcıların el yıkama konusundaki bilgi ve tutumlarını belirten kavramlardan olan ellerin ne zaman yıkanması gerektiği konusundaki bilgi ve tutumlarının olumlu olduğu saptanmıştır. Ancak el yıkama konusundaki bilgi ve tutumlarını belirten diğer kavramlardan; yemek hazırlığına başlamadan hemen önce elleri yıkamanın neden önemli olduğu, el yıkama işleminde kullanılan malzemelerin neler olduğu, yıkanmış ellerin kurulanmasında hangisinin tercih edildiği konularında doğru bilgi ve tutum sahibi olmayan kişi sayısının da azımsanmayacak miktarda olduğu görülmüştür (Tablo 3). Ayrıca, 
çalışmaya dahil edilen katılımcıların eğitim durumları ile "yemek hazırlığına başlamadan hemen önce elleri yıkamak neden önemlidir?" sorusuna verilen yanitlar arasında anlamlı fark $(p<0,05)$ tespit edilmiştir.

Demirci ve Ersoy [17]'un çalışmasında katılımcıların \%98,7'si işe başlamadan önce ellerini yıkadığını belirtmiştir. Ellerini yıkayan personelin \%86,9'unun sıvı sabun kullandığ1 ve \%83,6'sının ellerini havlu peçete ile kuruladıkları saptanmıştır. Bizim çalışmamızda tırnak firçası, sıcak su, dezenfektenlı el jelinin hepsinin el yıkama işleminde kullanılan malzeme olduğunu söyleyenlerin oranı $\% 49,2$ olarak bulunurken, yıkanmış ellerin kurulanmasında kağıt havluyu kullanırım diyenlerin oranı $\% 67,4$ olarak bulunmuştur (Tablo 3).

Pragle vd. [18] gıda işlemede görevli personeli izledikleri araştırmalarında; personelin gıda hazırlığına başlamadan önce ellerini genellikle yıkamadıklarını belirlemişlerdir.

Enç vd. [19] üniversite öğrencisi olan kişilerin el yıkama alışkanlıklarının incelendiği araştırmada, akarsuyun el y1kamada daha etkili olduğunu söyleyen öğrencilerin oranın $1 \% 53$, mikroorganizmaları yok etmek için ellerdeki yıkanması gereken bölgeleri ve yıkama süresini doğru şekilde ifade eden öğrencilerin oranını \%85 olarak bulmuştur.

Çıkmaz [20]'ın araştırmasında, hastane yemekhanesinde görev yapan çalışanların çoğunluğu $(\% 96,8)$ yemek hazırlığına başlamadan ve servisten önce ellerini yıkadıklarını belirtmiş, ancak araştırmacı işletme içerisinde edindiği izlenim neticesinde personelin ellerini yıkamak için gerekli olan temizlik maddesi ve kurulamak için gerekli olan kağıt havlunun el yıkama alanlarında olmadığını görmüştür.

Clayton ve Griffith [21]'in gida işlemede görev yapan 115 kişiyi izledikleri araştırmaya göre; potansiyel tehlike oluşturan gidalar ve yüzeylere dokunduktan sonra ellerini yıkayan personelin oranı $\% 32$, saçı veya yüzüne dokunduktan sonra ellerini yıkayan personelin oranı $\% 9$, mutfağa her girişinde ellerini yıkayan personelin oranı \%14, işleme sırasında kirli yüzeylere, ekipmanlara ve araçlara dokunduktan sonra ellerini yıkayan personelin oranı \%10, hijyenik el yıkama uygulamasını yapan personelin oranı ise \%31 olarak bulunmuştur. Oysa bizim çalışmamızda katılımcıların \%86,9'u ellerin "yemek hazırlığına başlamadan önce", "pişmemiş gidalara (sebze, meyve, et, tavuk, balık vb.,) temastan sonra", "yemek yemeden önce ve sonra", "tuvalete girerken ve çıktıktan sonra", "çöp ile temastan sonra" ve "hapşırma, öksürme gibi işlemlerden sonra" olmak üzere her durumda yıkanması gerektiğini belirtmiştir (Tablo 3). El yıkama konusunda yürütülen araştırmalarda mutfağa giriş yapmadan önce yıkanması gereken ellerin olması gerektiği sıklıkta yıkanmadığı, el ve giysi hijyeni konularında personelin uygulamalarının yetersiz olduğu görülmüştür [21, 22].

Green vd. [23] Amerika'da faaliyet gösteren 321 gıda işletmesindeki çalışanların sadece $\% 27$ 'sinin ellerini hijyen kurallarına uygun olarak yıkadığını bulmuştur. Pragle vd. [18], Clayton ve Griffith [21], Green vd. [23], Ural [24] tarafından gerçekleştirilen değişik çalışmalarda, mutfak personelinin çoğunun "farklı özelliğe sahip gıdalara dokunmadan önce", "çiğ gıda ile pişmiş gıdanın servisi sırasında çalışmayı değiştirmesi gerektiğinde" ya da "potansiyel tehlike oluşturan gıdalara dokunduktan sonra" el hijyenine olması gerektiği kadar hassasiyet göstermedikleri gözlemlenmiştir.

Altekruse vd. [25] el yıkama ya da çiğ ete temas ettikten sonra çapraz bulaşmaya sebep olmamak için uygun bir tedbir alma gibi, gerekli hijyen uygulamalarının doğru olmadığı personel sayısının araştırmaya katılan toplam personel sayısının üçte biri oranında olduğunu belirlemiştir.

Sivas ili merkez ilçesindeki 317 gıda üreten ve satışı yapan kuruluşta görev yapan 494 personelin ancak yarısının kişisel hijyene önem verdiği, lise ve üstü düzeyinde eğitim almış personelin kişisel hijyen konusunda daha iyi olduğu görülmüştür $(p<0,05)$. Ancak personelin sadece $\% 15,8$ 'i mikroorganizmaların eller tarafindan bulaşabileceğini ifade etmiştir [7].

ABD Hastalık Kontrol ve Önleme Merkezi, gıda kaynaklı hastalıkların \%19 oranında kişisel hijyen konusundaki yetersizlik ve uygun olmayan el yıkama işleminden kaynaklandığını belirtmiştir [26]. El temizliği için öncelikle ellerin yıkanması, sonra dezenfekte edilmesi, ardından ellerin firçalanması ve son olarak da elin kurulanması (kağıt havlu, antimikrobiyal madde emdirilmiş pamuk havlu ya da sicak hava akımında) gerekmektedir [27].

Gıdalar, direkt ve indirekt temaslar neticesinde oldukça farklı kaynaktan kontaminasyona uğrayabilirler. Bu kaynaklar başlıca; işletmede çalışan personeller, gıdanın temasta olduğu yüzeyler ve başka gıdalardır. Kişisel hijyene gereken önem verilerek ve özellikle eller doğru şekilde yıkanarak ve iş elbiseleri uygun şekilde temizlenerek kontaminasyonlar azaltılabilir. Gıdanın hazırlanması aşamasında da personelin hijyen kurallarına uyması kontaminasyonları azaltan diğer bir faktördür [28]. 
Gıda kaynaklı patojen mikroorganizmaların bulaşma kaynağının başında insanlar gelmektedir. İnsanların derisinde, saçlarında, elbisesinde birçok mikroorganizma bulunmakta ve bunlar insanların dokundukları diğer objelere geçebilmektedir. Bu nedenle gıda işlemede görev yapan personelin kişisel hijyenine dikkat etmesi, gıda işleme sırasında kendisinin en önemli kontaminasyon kaynağı olduğunu unutmaması gerekir [29]. Kontaminasyona maruz kalmış bir yüzey ya da bir bez personelin eliyle temas halinde olduğunda ve gıdalara veya gıdaların doldurulacağı kaplar ellendiğinde tehlikeli bir boyutta mikroorganizma geçişi olmaktadır [30]. Bu tür bulaşmaların oluşmaması için gıda hazırlığına başlamadan önce, gıda hazırlığı esnasında ve gıda hazırlığından sonra eller yıkanmalıdır. Özellikle de çiğ eti, sebzeyi, gıda dışındaki nesneleri elledikten sonra, tuvaletten çıktıktan sonra ellerin doğru şekilde yıkanmasının önemi kavranmalıdır [12]. Ellerin sıcak su ve sabun eşliğinde bütün kısımlarının bileklere kadar $20 \mathrm{~s}$ boyunca ovuşturularak yıkanması, yine bol akan sıcak suyla durulanması ve uygun bir dezenfeksiyonla, uygun miktarda dezenfekte edildikten sonra kendi halinde kurumasının beklenmesi gerektiği unutulmamalıdır. Katılımcıların mutfakta yemek hazırlama sırasında dikkat edilmesi gereken parametreler konusundaki bilgi düzeylerini belirten dağılım Tablo 4'te verilmiştir.

Tablo 4. Katılımciların mutfakta yemek hazırlama sırasında dikkat edilmesi gereken parametreler konusundaki bilgi düzeylerini belirten dağılım

\begin{tabular}{|c|c|c|}
\hline $\begin{array}{l}\text { 14. Mutfakta yemek hazırlığı ve pişirmesi sırasında aşağıdakilerden hangilerini } \\
\text { kullanırsınız? }\end{array}$ & Sayı & $\%$ \\
\hline a) Mutfak önlüğü & 254 & 42,6 \\
\hline b) Eldiven & 84 & 14,1 \\
\hline c) Bone ya da tülbent & 40 & 6,7 \\
\hline d) Hepsi* & 209 & 35,1 \\
\hline e) Hiçbiri & 9 & 1,5 \\
\hline Toplam & 596 & 100,0 \\
\hline \multicolumn{3}{|l|}{$\begin{array}{l}\text { 15. Mutfakta yemek hazırlığı sırasında yüzük, bilezik, saat vb., süs eşyalarınızı çıkarır } \\
\text { mısınız? }\end{array}$} \\
\hline a) Evet* & 473 & 79,3 \\
\hline b) Hayır & 123 & 20,7 \\
\hline Toplam & 596 & 100,0 \\
\hline \multicolumn{3}{|l|}{$\begin{array}{l}\text { 16. Mutfakta yemek hazırlığı sırasında kullanılan araç, gereç, alet vb., temizliğini ne } \\
\text { sıklıkla yaparsınız? }\end{array}$} \\
\hline a) Biriken diğer bulaşıklarla birlikte uygun bir ara yıkarım & 63 & 10,6 \\
\hline b) Kullanıldığı gün tüm işler bittikten sonra sıcak su ve temizlik malzemeleriyle yıkarım & 187 & 31,4 \\
\hline c) Kullanıldıktan hemen sonra sıcak su ve temizlik malzemeleriyle yıkarım* & 346 & 58,0 \\
\hline Toplam & 596 & 100,0 \\
\hline \multicolumn{3}{|l|}{ 17. Çöp kovası yemek hazırlarken nerede ve nasıl bulunmalıdır? } \\
\hline a) Hazırlama-pişirme alanına ve buzdolabına yakın bir yerde, üstü açık olarak & 28 & 4,7 \\
\hline b) Hazırlama-pişirme alanına ve buzdolabına yakın bir yerde, üstü kapalı olarak & 132 & 22,1 \\
\hline c) Hazırlama-pişirme alanına ve buzdolabına uzakta, üstü kapalı olarak* & 410 & 68,8 \\
\hline d) Hazırlama-pişirme alanına ve buzdolabına uzakta, üstü açık olarak & 26 & 4,4 \\
\hline Toplam & 596 & 100,0 \\
\hline \multicolumn{3}{|l|}{ 18. Aşağıdakilerden hangisi gıda kesme işleminde kullanılması uygun yüzeydir? } \\
\hline a) Fayans & 46 & 7,7 \\
\hline b) Tahta kesme yüzeyi & 337 & 56,5 \\
\hline c) Sertleştirilmiş plastik blok* & 64 & 10,7 \\
\hline d) Cam kesme yüzeyi & 149 & 25,0 \\
\hline Toplam & 596 & 100,0 \\
\hline \multicolumn{3}{|l|}{ 19. Yemek hazırlığı sırasında aşağıdakilerden hangisi tehlike oluşturur? } \\
\hline a) Önlük takılması & 20 & 3,4 \\
\hline b) Ellerin uygun şekilde yıkanması & 18 & 3,0 \\
\hline c) Dezenfekte edilmiş mutfak ekipmanının kullanılması & 18 & 3,0 \\
\hline d) Kirli ve temiz mutfak ekipmanının aynı ortamda bulunması* & 540 & 90,6 \\
\hline Toplam & 596 & 100,0 \\
\hline
\end{tabular}

*Anket sorusunun doğru cevabıdır. 
Katılımcıların \%42,6'sının mutfakta yemek hazırlığı ve pişirmesi sırasında mutfak önlüğü, \%14,1'inin eldiven, \%6,7'sinin bone veya tülbent kullandığ tespit edilirken; \%1,5'inin hiçbirini kullanmadığı belirlenmiştir. Doğru yanıt olan "hepsi" seçeneğini işaretleyenlerin oranı \%35,1 olmuştur (Tablo 4).

Katılımcıların \%79,3'ü doğru olan yanıtı işaretleyerek; mutfakta yemek hazırlığı sırasında takılarını çıkardığını, \%20,7'si ise çıkarmadığını ifade etmiştir (Tablo 4).

Mutfakta kullandıkları araç, gereç, alet vb. temizliğini ne sıklıkla yaptıkları sorgulandığında; $\% 10,6$ 's "biriken diğer bulaşıklarla birlikte uygun bir ara yıkarım", \%31,4'ü "kullanıldığı gün tüm işler bittikten sonra sıcak su ve temizlik malzemeleriyle yıkarım", \%58,0'i doğru yanıtı işaretleyerek; "kullanıldıktan hemen sonra sıcak su ve temizlik malzemeleriyle yıkarım" şeklinde cevap vermiştir (Tablo 4).

"Çöp kovası yemek hazırlarken nerede ve nasıl bulunmalıdır?" sorusuna ankete katılan katılımcılardan \%4,7'sinin "hazırlama-pişirme alanına ve buzdolabına yakın bir yerde, üstü açık olarak", \%22,1'inin "hazırlama-pişirme alanına ve buzdolabına yakın bir yerde, üstü kapalı olarak", \%4,4'ünün "hazırlama-pişirme alanına ve buzdolabına uzakta, üstü açık olarak" yanıtını verdiği görülmüştür. Doğru yanıt olan "hazırlama-pişirme alanına ve buzdolabına uzakta, üstü kapalı olarak" cevabını verenlerin oranı \%68,8 olmuştur (Tablo 4).

Katılımcıların \% 7,7'si fayansın, \%56,5'i tahta kesme yüzeyinin, \%25,0'i cam kesme yüzeyinin gıda kesme işleminde kullanılması uygun yüzey olduğunu ileri sürerken; sadece $\% 10,7$ 'si doğru yanıt olan "sertleştirilmiş plastik bloğu" işaretlemiştir (Tablo 4).

Katılımcıların \%3,4'ü yemek hazırlığı sirasında önlük takılmasının, \%3,0’ü ellerin uygun şekilde yıkanmasının, \%3,0'ü dezenfekte edilmiş mutfak ekipmanının kullanılmasının tehlike oluşturduğunu belirtirken; \%90,6'sı doğru yanıtı işaretleyerek; kirli ve temiz mutfak ekipmanının aynı ortamda bulunmasının tehlike oluşturduğunu belirtmiştir (Tablo 4).

Katılımcıların mutfakta yemek hazırlama sırasında dikkat edilmesi gereken parametreler konusundaki bilgi düzeylerini ortaya koyan; mutfakta yemek hazırlığı ve pişirmesi sırasında hangi koruyucu malzemelerin kullanıldığı, mutfakta yemek hazırlığı sırasında yüzük, bilezik, saat vb. süs eşyalarını çıkarıp çıkarmadığı, mutfakta yemek hazırlığı sırasında kullanılan araç, gereç, alet vb. temizliğinin ne sıklıkla yapıldığı, çöp kovasının yemek hazırlarken nerede ve nasıl bulunması gerektiği, gıda kesme işleminde kullanılması uygun yüzeyin hangisi olduğu konularında doğru bilgi ve tutum sahibi olmayan kişi sayısının azımsanmayacak miktarda olduğu görülmüştür. Ancak, katılımcıların \%90,6'sının mutfakta yemek hazırlama sirasında dikkat edilmesi gereken parametreler konusundaki bilgi düzeylerini gösteren diğer bir kavram olan; yemek hazırlığı sırasında tehlike oluşturan uygulamaların hangisi olduğu konusunda doğru bilgi sahibi oldukları ortaya çıkmıştır (Tablo 4).

Askarian vd. [5]'nin çalışmasında; eldiven, bone ve maske gibi koruyucuları kullanmanın gıdalarda kontaminasyonu önlediğini ifade edenler \%95,5 oranında bulunmuştur. Oysa bizim çalışmamızda mutfakta yemek hazırlığı ve pişirmesi sırasında mutfak önlüğü, eldiven ve bone ya da tülbendin hepsinin kullanılması gerektiğini belirten katılımcıların oranı $\% 35,1$ bulunmuştur (Tablo 4).

Green vd. [23]; çalışanların mutfakta gerçekleştirdikleri iş aşamalarının sadece \%28'inde eldiven taktıklarını bulmuştur.

Gıda hazırlığı aşamasında uygun bir koruyucu önlük muhakkak takılmalı ve saçların gıda içerisine düşmemesi için saç bonesi kullanılmalıdır. Takılan koruyucu önlüklerin temizliğinin de periyodik olarak yapılması gerekmektedir [2, 31-33]. Koruyucu önlüklerin üzerine bulaşan gida artıklarının bir sonraki gıda ürünlerine bulaşmasının önlenmesi için önlükler sık sık değiştirilmeli ve ayrıca çamaşır makinesinde yüksek sıcaklıklarda yıkanarak etkin şekilde temizlenmelidir [12].

Howes vd. [34]; ABD' deki araştırmasında gıda kaynaklı hastalıkların \%97'sinin genellikle gıda işlemede görev alan kişilerin gıda hazırlığı aşamasındaki hijyenik olmayan uygulamalarından kaynaklandığını rapor etmişlerdir.

Çalışmamızda "mutfakta yemek hazırlığı sırasında kullanılan araç, gereç, alet vb., temizliğini ne sıklıkla yaparsınız?" sorusuna; "kullanıldıktan hemen sonra sıcak su ve temizlik malzemeleriyle yıkarım" cevabını veren katılımcıların oranı \%58,0 olarak belirlenmiştir (Tablo 4). Sneed vd. [35]; ABD'de yürüttükleri araştırmada gıdalarda çapraz kontaminasyona sebep olabilecek, gıda ile temas eden yüzeylerdeki mikrobiyolojik kalitenin tespit edilmesinde yapılan temizlik ve sanitasyonun etkisini incelemiştir. Sonuç olarak, bu yüzeylerin az bir miktarının temizlik ve sanitasyonunun kurallara uygun olduğu, gıdayla temas eden yüzeylerin hijyenine gereken önem verilmediğinde çapraz kontaminasyonun 
tehlikeli boyutlarda olabileceğini saptamışlardır [35]. Bizim çalışmamızda da katılımcıların bu konuda hassas davranmadıkları görülmüştür.

İnsan vücudunun doğal florasında bulunan bazı patojen mikroorganizmaların gıdayla temas eden yüzeylerle de bulunabileceği ve bir gıdadan diğer bir gıdaya kolaylıkla taşınabileceği göz ardı edilmemelidir. Çiğ gıdayla veya personel sebebiyle bulaşmalara maruz kalabilecek, gıdalarla sürekli temas halinde olan yüzeyler bulunmaktadır. Örneğin, çiğ et gıda kesim tahtasında doğrandıktan sonra, salata malzemeleri de aynı tahta üzerinde kesilirse, ilk kullanımda tahtaya kontamine olmuş etteki mikroorganizmaların bir kısmının salataya bulaşması kaçınılmazdır [28].

Bu sebeple gıdalar hazırlanırken çĭ̆ ve pişmiş haldeki ürünler ayrı yerlerde bekletilmelidir. Çĭğ ürünleri işlerken tek sefer kullanılıp atılan eldivenler takılmalı, soyulup doğranan ve temiz su ile yıkanan ürünler hızlı bir şekilde pişirme kısmına getirilmelidir. Pişmiş̧ gıdalar kontaminasyona sebep vermemek için çiğ gıdalarla karşılaştırılmamalıdır [8, 35]. Çalışmamızda katılımcıların \%90,6'sının kirli ve temiz mutfak ekipmanının aynı ortamda bulunmasının yemek hazırlığı sırasında tehlike oluşturduğunu belirtmesi (Tablo 4) katılımcıların çapraz bulaşma konusunda bilinçli olduğunu göstermiştir.

ABD Hastalık Kontrol ve Önleme Merkezi, kontamine olmuş ekipmanların gıda kaynaklı hastalıklara sebep olma oranını \%16 olarak belirtmiştir [6]. Özellikle kesme tahtaları, genel temizlik ve bulaşı yıkama süngerleri, temizlik veya el kurulama bezleri, ellerin veya gıda ürünlerinin yıkandığı lavabolar, çalışma tezgahları gibi ekipmanlar ve yüzeyler mikrobiyal bulaşmanın nedeni olarak görülmektedir [12].

$\mathrm{Bu}$ malzemelerin temizliği sıcak su içerinde uygun temizlik maddesi ve klorlu ağartıcılar eşliğinde uygun periyotlarda gerçekleştirilmeli, sünger, havlu, bez gibi ucuz ve kolay elde edilebilen malzemeler sıklıkla değiştirilmelidir [12]. Kesme tahtaları her kullanımdan sonra önce uygun temizlik maddesi ile temizlenmeli ve sonra klorlu bir ağartıcı içeren suyla dezenfekte edilmelidir. Bunun için bir su bardağı $(250 \mathrm{~mL})$ su içerisine iki çay kaşı̆̆ı kadar çamaşır suyu eklenerek hazırlanan karışım kullanılabilir [36].

Katılımcıların yemeği pişirme ve saklama aşamalarında dikkat edilmesi gereken parametreler konusundaki bilgi düzeylerini belirten dağılım Tablo 5 'te sunulmuştur.

Tablo 5. Katılımcıların yemeği pişirme ve saklama aşamalarında dikkat edilmesi gereken parametreler konusundaki bilgi düzeylerini belirten dağılım

\begin{tabular}{|c|c|c|}
\hline 20. Pişen et, tavuk ya da balığın iç sıcaklığı aşağıdaki şıklardan hangisi olmalıdır? & Sayı & $\%$ \\
\hline a) $35-45^{\circ} \mathrm{C}$ & 112 & 18,8 \\
\hline b) $65-75^{\circ} \mathrm{C}^{*}$ & 269 & 45,1 \\
\hline c) $45-55^{\circ} \mathrm{C}$ & 204 & 34,2 \\
\hline d) Bilmiyorum & 11 & 1,8 \\
\hline Toplam & 596 & 100,0 \\
\hline \multicolumn{3}{|l|}{ 21. Pişmiş yemekte lezzet kontrolü nasıl yapılmalıdır? } \\
\hline a) Temiz bir kaşıkla yemekten çok küçük bir miktar direkt ağıza veya bir kaba alınarak tadılır* & 466 & 78,2 \\
\hline b) Yemekten elle bir parça alınıp tadılır & 23 & 3,9 \\
\hline $\begin{array}{l}\text { c) Yemeğin tuzu vb., katkılarının konulduğu, karıştırma vb., işlemlerin yapıldığı kaşık veya } \\
\text { çatalla tadılmalıdır }\end{array}$ & 101 & 16,9 \\
\hline d) Bilmiyorum & 6 & 1,0 \\
\hline Toplam & 596 & 100,0 \\
\hline \multicolumn{3}{|l|}{ 22. Pișen yemek hemen tüketilmeyecekse ne yapılmalıdır? } \\
\hline a) Hemen üstü kapalı olarak buzdolabına kaldırılmalıdır & 102 & 17,1 \\
\hline b) Ocak ya da firın üzerinde üstü kapalı olarak soğuduktan sonra buzdolabına kaldırılmalıdır* & 465 & 78,0 \\
\hline c) Servis edilinceye dek mutfakta bekletilmelidir & 28 & 4,7 \\
\hline d) Fikrim yok & 1 & 0,2 \\
\hline Toplam & 596 & 100,0 \\
\hline \multicolumn{3}{|l|}{$\begin{array}{l}\text { 23. Yeniden ısıtma işlemine tabi tutulacak et ve balık yemekleri en az kaç dereceye kadar } \\
\text { Isıtılmalıdır? }\end{array}$} \\
\hline a) $55-65^{\circ} \mathrm{C}$ & 253 & 42,4 \\
\hline b) $65-70^{\circ} \mathrm{C}$ & 198 & 33,2 \\
\hline c) $70-75^{\circ} \mathrm{C}^{*}$ & 93 & 15,6 \\
\hline d) $90-95^{\circ} \mathrm{C}$ & 44 & 7,4 \\
\hline e) Bilmiyorum & 8 & 1,3 \\
\hline Toplam & 596 & 100,0 \\
\hline
\end{tabular}

*Anket sorusunun doğru cevabıdır. 
Katılımcıların \%18,8'i pişen et, tavuk ya da balığın iç sıcaklığının " $35-45^{\circ} \mathrm{C}$ ”, \%34,2'si “45-55 ${ }^{\circ} \mathrm{C}$ " olması gerektiğini, \%1,8'i ise bilmediğini ifade etmiştir. Doğru yanıt olan "65-75 ${ }^{\circ} \mathrm{C}$ " yanıtını işaretleyenlerin oran $1 \% 45,1$ olmuştur (Tablo 5).

Pişmiş yemekte lezzet kontrolünün nasıl yapılması gerektiği sorulduğunda; katılımcıların \%78,2'si doğru yanıt olan; temiz bir kaşıla yemekten çok küçük bir miktar direkt ağıza veya bir kaba alınarak tadılması gerektiğini, \%3,9'u yemekten elle bir parça alınıp tadılması gerektiğini, \%16,9'u yemeğin tuzu vb. katkılarının konulduğu, karıştırma vb. işlemlerin yapıldığı kaşık veya çatalla tadılması gerektiğini, \%1,0'i ise karar veremeyerek "bilmiyorum" seçeneğini işaretlemiştir (Tablo 5).

"Pişen yemek hemen tüketilmeyecekse ne yapılmalıdır?" sorusuna ankete katılan katılımcıların $\% 17,1$ 'i "hemen üstü kapalı olarak buzdolabına kaldırılmalıdır", \%4,7'si "servis edilinceye dek mutfakta bekletilmelidir" cevabını verirken; bir kişi fikrinin olmadığını belirtmiştir. Katılımcıların \%78,0'i doğru yanıt olan; "ocak ya da firın üzerinde üstü kapalı olarak soğuduktan sonra buzdolabına kaldırılmalıdır" seçeneğini işaretlemiştir (Tablo 5).

Katılımcıların \%42,4'ü yeniden 1sıtma işlemine tabi tutulacak et ve balık yemeklerinin en az 55$65{ }^{\circ} \mathrm{C}^{\prime}$ ye kadar, \%33,2'si $65-70{ }^{\circ} \mathrm{C}$ 'ye kadar, \%7,4'ü 90-95 ${ }^{\circ} \mathrm{C}^{\prime}$ ye kadar 1sitılmas1 gerektiğini ifade ederken; \%1,3'ü bilmediğini belirtmiştir. Katılımcıların sadece \%15,6's1 doğru yanıt olan $70-75^{\circ} \mathrm{C}^{\prime}$ ye kadar ssitılması gerektiğini işaretlemiştir (Tablo 5).

Katılımcıların yemeği pişirme ve saklama aşamalarında dikkat edilmesi gereken parametreler konusundaki bilgi düzeylerini gösteren kavramlardan; pişen et, tavuk ya da balığın iç sıcaklığının ne kadar olması gerektiği, pişmiş yemekte lezzet kontrolü nasıl yapılması gerektiği, pişen yemek hemen tüketilmeyecekse ne yapılması gerektiği, yeniden ısıtma işlemine tabi tutulacak et ve balık yemekleri en az kaç dereceye kadar ısıtılması gerektiği konularında doğru bilgi ve tutum sahibi olmayan kişi sayısının azımsanmayacak miktarda olduğu görülmüştür (Tablo 5).

ABD Hastalık Kontrol ve Önleme Merkezi, yetersiz pişirmenin gıda kaynaklı hastalıklara sebep olma oranını \% 11 olarak belirtmiştir [6].

Yapılan bir çalışmada bizim çalı̧̧mamızdan farklı olarak; güvenli pişirme uygulaması yapan tüketicilerin oranının oldukça fazla olduğu belirlenmiştir. Ancak pişmiş gıdalara elle dokunma, tekrar 1sıtmada gıdanın iç sıcaklığının uygun dereceye kadar yükselmesinin beklenmemesi, pişen gıdanın oda sıcaklığında uzun süre tutulması gibi doğru olmayan uygulamaların bazı tüketiciler tarafindan gerçekleştirildiği görülmüştür [37].

Bütün gıda maddeleri kendilerine uygun sıcaklık derecesinde, yeterli süre pişirilmeli ve mümkün olan en kısa zaman içerisinde yenmelidir. Bu yüzden gıdaların en iyi şekilde pişebileceği minimum iç sıcaklık dereceleri öğrenilmeli ve uygulanmalıdır [6, 8]. Fischer vd. [38] gıda kaynaklı hastalıkların bertaraf edilmesinde uygun sicaklık derecesinde pişirme ve çapraz bulaşmaya dikkat edilmesi konusunda tüketicilerin çoğunun bilgi sahibi olduğunu belirlemiştir. Fakat sahip olunan bilginin doğru uygulama için yeterli olmadığı, uygulamaların doğru şekilde yapılarak davranış haline dönüştürülmesinde daha çok alışkanlıkların ön plana çıktığı görülmüştür [38].

Katılımcıların bazı sorulara verdikleri cevapların eğitim durumuna göre dağılımları $(p<0,05)$ Tablo 6'da sunulmuştur.

Katılımcıların "hijyen nedir?" sorusuna verdikleri cevaplar ile eğitim durumları arasındaki farkın anlamlı $\left(p=0,038, \chi^{2}=8,397\right)$ olduğu tespit edilmiştir. İlköğretim mezunu katılımcıların $\% 91,5$ 'i, lise mezunu katılımcıların \%82,5'i, lisans mezunu katılımc1ların \%90,3'ü, lisansüstü mezunu katılımcıların \%95,1'i hijyenin hem görünen kirlerin uzaklaştırılması (temizlik) hem de görünmeyen kirin uzaklaştırılması (dezenfekte etmek) olduğunu belirtmiş̧ir (Tablo 6).

Katılımcıların "hangisi gida zehirlenmelerine sebep olur?" sorusuna verdikleri yanıtlar ile eğitim durumları arasındaki farkın anlamlı $\left(p=0,001, \chi^{2}=16,722\right)$ olduğu belirlenmiştir. İlköğretim mezunu katılımcıların sadece \%21,3'ü, lise mezunu katılımcıların ise \%54,0'ü, doğru olan, gida zehirlenmelerine patojen (hastalık yapıc1) bakterilerin sebep olduğu yanıtını işaretlemiştir (Tablo 6).

Katılımcıların "mutfakta mikroorganizmaların yayılmasında hangisi etkili olur?" sorusuna verdikleri cevaplar ile eğitim durumları arasındaki farkın anlamlı $\left(p=0,005, \chi^{2}=12,648\right)$ olduğu bulunmuştur. Bu soruya doğru yanıt olan "hepsi" cevabını veren katılımcıların dağılımının lisansüstü mezunlarında \%92,7, lisans mezunlarında \%78,7, lise mezunlarında \%72,3 iken; ilköğretim mezunlarında \%63,8 olduğu saptanmıştır (Tablo 6). 
Tablo 6. Katılımcıların bazı sorulara verdikleri cevapların eğitim durumuna göre dağılımları $(p<0,05)$

\begin{tabular}{|c|c|c|c|c|c|c|c|c|c|c|}
\hline \multirow[t]{2}{*}{ Soru } & \multirow[t]{2}{*}{ Yanit } & \multicolumn{2}{|c|}{$\begin{array}{c}\text { İlköğretim } \\
\text { (sayı=47) }\end{array}$} & \multicolumn{2}{|c|}{$\begin{array}{c}\text { Lise } \\
\text { (sayl=137) }\end{array}$} & \multicolumn{2}{|c|}{$\begin{array}{c}\text { Lisans } \\
\text { (sayl=371) }\end{array}$} & \multicolumn{2}{|c|}{$\begin{array}{c}\text { Lisansüstü } \\
(\text { sayı }=41)\end{array}$} & \multirow[t]{2}{*}{$p, \chi^{2}$} \\
\hline & & sayı & $\%$ & sayı & $\%$ & sayl & $\%$ & sayı & $\%$ & \\
\hline \multirow{2}{*}{ 1. Hijyen nedir? } & Doğru & 43 & 91,5 & 113 & 82,5 & 335 & 90,3 & 39 & 95,1 & \multirow{2}{*}{$\begin{array}{l}0,038, \\
8,397\end{array}$} \\
\hline & Yanlış & 4 & 8,5 & 24 & 17,5 & 36 & 9,7 & 2 & 4,9 & \\
\hline \multirow{2}{*}{$\begin{array}{l}\text { 2. Hangisi gida zehirlenmelerine } \\
\text { sebep olur? }\end{array}$} & Doğru & 10 & 21,3 & 74 & 54,0 & 157 & 42,3 & 21 & 51,2 & \multirow{2}{*}{$\begin{array}{l}0,001, \\
16,722\end{array}$} \\
\hline & Yanlış & 37 & 78,7 & 63 & 46,0 & 214 & 57,7 & 20 & 48,8 & \\
\hline \multirow{2}{*}{$\begin{array}{l}\text { 3. Mutfakta } \\
\text { mikroorganizmaların } \\
\text { yayılmasinda hangisi etkili } \\
\text { olur? }\end{array}$} & Doğru & 30 & 63,8 & 99 & 72,3 & 292 & 78,7 & 38 & 92,7 & \multirow{2}{*}{$\begin{array}{l}0,005 \\
12,648\end{array}$} \\
\hline & Yanlış & 17 & 36,2 & 38 & 27,7 & 79 & 21,3 & 3 & 7,3 & \\
\hline \multirow{2}{*}{$\begin{array}{l}\text { 13. Yıkanmış ellerin } \\
\text { kurulanmasında } \\
\text { aşağıdakilerden hangisini tercih } \\
\text { edersiniz? }\end{array}$} & Doğru & 27 & 57,4 & 85 & 62,0 & 253 & 68,2 & 35 & 85,4 & \multirow{2}{*}{$\begin{array}{l}0,019, \\
9,970\end{array}$} \\
\hline & Yanlış & 20 & 42,6 & 52 & 38,0 & 118 & 31,8 & 6 & 14,6 & \\
\hline \multirow{2}{*}{$\begin{array}{l}\text { 14. Mutfakta yemek hazırlığı ve } \\
\text { pişirmesi sırasında } \\
\text { aşağıdakilerden hangilerini } \\
\text { kullanırsınız? }\end{array}$} & Doğru & 26 & 55,3 & 73 & 53,3 & 96 & 25,9 & 14 & 34,1 & \multirow{2}{*}{$\begin{array}{l}0,000 \\
42,213\end{array}$} \\
\hline & Yanlış & 21 & 44,7 & 64 & 46,7 & 275 & 74,1 & 27 & 65,9 & \\
\hline \multirow{2}{*}{$\begin{array}{l}\text { 20. Pişen et, tavuk ya da balığın } \\
\text { iç sıcaklığı aşağıdaki şıklardan } \\
\text { hangisi olmalıdır? }\end{array}$} & Doğru & 23 & 48,9 & 59 & 43,1 & 161 & 43,4 & 26 & 63,4 & \multirow{2}{*}{$\begin{array}{l}0,090 \\
6,496\end{array}$} \\
\hline & Yanlış & 24 & 51,1 & 78 & 56,9 & 210 & 56,6 & 15 & 36,6 & \\
\hline
\end{tabular}

Katılımcıların "yıkanmış ellerin kurulanmasında aşağıdakilerden hangisini tercih edersiniz?" sorusuna verdikleri yanıtlar ile eğitim durumları arasındaki fark anlamlı $\left(p=0,019, \chi^{2}=9,970\right)$ bulunmuştur. İlköğretim mezunlarının \%57,41'ü, lise mezunlarının \%62,0'si, lisans mezunlarının \%68,2'si, lisansüstü mezunlarının \%85,4'ü, doğru yanıt olan "kağıt havlu" seçeneğini işaretlemiştir (Tablo 6).

Katılımcıların "mutfakta yemek hazırlığı ve pişirmesi sırasında aşağıdakilerden hangilerini kullanırsınız?" sorusuna verdikleri yanıtlar ile eğitim durumları arasındaki farkın anlamlı $(p=0,000$, $\chi^{2}=42,213$ ) olduğu belirlenmiştir. İlköğretim mezunlarının \%55,3'ü ve lise mezunlarının \%53,3'ü yemek hazırllğ 1 ve pişirmesi sırasında mutfak önlügü, eldiven ve bone ya da tülbendin hepsini kullandığını ifade etmiştir (Tablo 6).

Katılımcıların "pişen et, tavuk ya da balığın iç sıcaklığı aşağıdaki şıklardan hangisi olmalıdır?" sorusuna verdikleri cevaplar ile eğitim durumları arasındaki farkın anlamlı $\left(p=0,090, \chi^{2}=6,496\right)$ olduğu görülmüştür. İlköğretim mezunlarının $\% 48,9$ 'u, lise mezunlarının $\% 43,1$ 'i, lisans mezunlarının $\% 43,4$ 'ü, lisansüstü mezunlarının $\% 63,4$ 'ü, “ $65-75^{\circ} \mathrm{C}$ ” olmas1 gerektiğini belirtmiştir (Tablo 6).

Bireylerin eğitim seviyesi arttıkça gıda güvenliği ve hijyen konularındaki bilgi ve tutumlarının daha doğru olması gerektiğini beklediğimiz çalışmamızda; bunun için eğitim seviyesinin yükselmesinin yetmediği, gıda güvenliği ve hijyen konularıyla ilgili eğitimlerin ayrıca alınması ve sürekliliğinin sağlanmasının ve öğrenilen doğru bilgilerin uygulanarak alışkanlık haline getirilmesinin gerektiği anlaşılmıştır. 
Nitekim, Kutluay Merdol vd. [3] kurum mutfağında görev yapan çalışanların hijyen bilgi düzeyi, tutum ve davranışları üzerinde verilen hijyen eğitiminin etkisini değerlendirmek amacıyla yürüttükleri araştırmalarında; eğitim öncesi ve eğitim sonrasındaki hijyen bilgi puanları arasında anlamlı fark $(p<0,05)$ olduğunu belirlemişlerdir. Worsfold ve Griffith [39] orta ve küçük ölçekli olarak faaliyet gösteren 66 gıda işletmesinde sorumlu yönetici olarak görev yapan katılımcılar arasında yüksek düzeyde hijyen bilgisine sahip olanların oranının \%22 olduğunu saptamıştır. Clayton [40], gıdayla ilgili çeşitli yerlerde çalışan 137 kişiden \%95'inin daha önce gıda hijyeni eğitimi aldıklarını, ancak \%63'ünün ilgili soruların doğru yanıtlarını bazen bildiklerini, çoğunlukla uygulamadıklarını belirlemiş, bunun sebebi olarak da zamanın kısıtlı olması, personelin ve gerekli kaynağın yetersiz oluşunun öne sürüldüğünü görmüştür.

Katılımcıların bazı sorulara verdikleri cevapların cinsiyete göre dağılımları Tablo 7'de sunulmuştur.

\begin{tabular}{|c|c|c|c|c|c|c|}
\hline \multirow{2}{*}{ Soru } & \multirow{2}{*}{ Yanit } & \multicolumn{2}{|c|}{$\begin{array}{c}\text { Kadın } \\
(\text { sayı }=362)\end{array}$} & \multicolumn{2}{|c|}{$\begin{array}{c}\text { Erkek } \\
(\text { sayl }=234)\end{array}$} & \multirow{2}{*}{$p, \chi^{2}$} \\
\hline & & sayl & $\%$ & sayl & $\%$ & \\
\hline \multirow{2}{*}{$\begin{array}{l}\text { 7. Paketli halde satılan donmuş et ürünü (kırmızı et, } \\
\text { tavuk, balık, karides veya kalamar) alırken en çok } \\
\text { nelere dikkat edilmelidir? }\end{array}$} & Doğru & 288 & 79,6 & 186 & 79,5 & \multirow{2}{*}{$\begin{array}{l}0,342, \\
3,342\end{array}$} \\
\hline & Yanlış & 74 & 20,4 & 48 & 20,5 & \\
\hline \multirow{2}{*}{$\begin{array}{l}\text { 8. Donmuş et ürünü (kırmızı et, tavuk, balık, karides } \\
\text { veya kalamar) temin edildiyse pişirmeden önce nasıl } \\
\text { çözülmesini sağlarsını? }\end{array}$} & Doğru & 117 & 32,3 & 71 & 30,3 & \multirow{2}{*}{$\begin{array}{l}0,526 \\
2,229\end{array}$} \\
\hline & Yanlış & 245 & 67,7 & 163 & 69,7 & \\
\hline \multirow{2}{*}{$\begin{array}{l}\text { 9. Pişirmek üzere aldığınız donmuş et ürününü } \\
\text { (kırmızı et, tavuk, balık, karides veya kalamarı) } \\
\text { çözündürdünüz, ancak pişiremediniz, tekrar } \\
\text { dondurur musunuz? }\end{array}$} & Doğru & 310 & 85,6 & 186 & 79,5 & \multirow{2}{*}{$\begin{array}{l}0,039 \\
4,245\end{array}$} \\
\hline & Yanlış & 52 & 14,4 & 48 & 20,5 & \\
\hline \multirow{2}{*}{$\begin{array}{l}\text { 11. Yemek hazırlığına başlamadan hemen önce elleri } \\
\text { ylkamak neden önemlidir? }\end{array}$} & Doğru & 286 & 79,0 & 163 & 69,7 & \multirow{2}{*}{$\begin{array}{l}0,018, \\
10,114\end{array}$} \\
\hline & Yanlış & 76 & 21,0 & 71 & 30,3 & \\
\hline \multirow{2}{*}{$\begin{array}{l}\text { 12. Hangisi el yıkama işleminde kullanılan } \\
\text { malzemedir? }\end{array}$} & Doğru & 181 & 50,0 & 111 & 47,4 & \multirow{2}{*}{$\begin{array}{l}0,165 \\
5,091\end{array}$} \\
\hline & Yanlış & 181 & 50,0 & 123 & 52,6 & \\
\hline \multirow{2}{*}{$\begin{array}{l}\text { 13. Yıkanmış ellerin kurulanmasında aşağıdakilerden } \\
\text { hangisini tercih edersiniz? }\end{array}$} & Doğru & 243 & 67,1 & 158 & 67,5 & \multirow{2}{*}{$\begin{array}{l}0,317 \\
2,297\end{array}$} \\
\hline & Yanlış & 119 & 32,9 & 76 & 32,5 & \\
\hline \multirow{2}{*}{$\begin{array}{l}\text { 14. Mutfakta yemek hazırlığı ve pişirmesi sırasında } \\
\text { aşağıdakilerden hangilerini kullanırsınız? }\end{array}$} & Doğru & 125 & \begin{tabular}{|l|}
34,5 \\
\end{tabular} & 86 & 36,8 & \multirow{2}{*}{$\begin{array}{l}0,009 \\
13,522\end{array}$} \\
\hline & Yanlış & 237 & 65,5 & 148 & 63,2 & \\
\hline \multirow{2}{*}{$\begin{array}{l}\text { 16. Mutfakta yemek hazırlığı sırasında kullanılan } \\
\text { araç, gereç, alet vb., temizliğini ne sıklıkla } \\
\text { yaparsinı? }\end{array}$} & Doğru & 230 & 63,5 & 114 & 48,7 & \multirow{2}{*}{$\begin{array}{l}0,000, \\
22,847\end{array}$} \\
\hline & Yanlış & 132 & 36,5 & 120 & 51,3 & \\
\hline \multirow{2}{*}{$\begin{array}{l}\text { 20. Pişen et, tavuk ya da balığın iç sıcaklığı aşağıdaki } \\
\text { şıklardan hangisi olmalıdır? }\end{array}$} & Doğru & 152 & 42,0 & 118 & 50,4 & \multirow{2}{*}{$\begin{array}{l}0,034 \\
8,702\end{array}$} \\
\hline & Yanlış & 210 & 58,0 & 116 & 49,6 & \\
\hline \multirow{2}{*}{ 21. Pişmiş yemekte lezzet kontrolü nasıl yapılmalıdır? } & Doğru & 284 & 78,5 & 181 & 77,4 & \multirow{2}{*}{$\begin{array}{l}0,183 \\
4,848\end{array}$} \\
\hline & Yanlış & 78 & 21,5 & 53 & 22,6 & \\
\hline \multirow{2}{*}{$\begin{array}{l}\text { 23. Yeniden isıtma işlemine tabi tutulacak et ve balık } \\
\text { yemekleri en az kaç dereceye kadar isitılmalıdır? }\end{array}$} & Doğru & 56 & 15,5 & 37 & 15,8 & \multirow{2}{*}{$\begin{array}{l}0,016 \\
12,180\end{array}$} \\
\hline & Yanlış & 306 & 84,5 & 197 & 84,2 & \\
\hline
\end{tabular}

Tablo 7. Katılımcıların bazı sorulara verdikleri yanıtların cinsiyete göre dağıılımları

Cinsiyet ile "paketli halde satılan donmuş et ürünü (kırmızı et, tavuk, balık, karides veya kalamar) alırken en çok nelere dikkat edilmelidir?" sorusuna verilen yanıtlar arasındaki farkın anlamlı olmadığ $1\left(p=0,342, \chi^{2}=3,342\right)$ bulunmuştur. Kadınların \%79,6'sı, erkeklerin \%79,5'i donmuş et ürünü 
(kırmızı et, tavuk, balık, karides veya kalamar) alırken; paketin sağlamlığı, son kullanma tarihi ve ürünün görüntüsü parametrelerinden hepsine baktığını söylemiştir (Tablo 7).

Karakuş ve Küçükkömürler [12] tarafından gıda satın alırken her zaman/genelde son kullanma tarihine bakan kadınların oranının \%85,3 olarak tespit edilmesi bizim çalışmamızla benzerdir.

Cinsiyet ile "donmuş et ürünü (kırmızı et, tavuk, balık, karides veya kalamar) temin edildiyse pişirmeden önce nasıl çözülmesini sağlarsınız?" sorusuna verilen yanıtlar arasındaki farkın anlamlı olmadığı $\left(p=0,526, \chi^{2}=2,229\right)$ belirlenmiştir. Kadınların \%32,3'sı, erkeklerin \%30,3'ü donmuş eti "buzdolabında bekleterek" çözdürdügünü ifade etmiştir (Tablo 7).

Koçak [15] tarafindan donmuş etleri dolapta alt rafa indirerek çözdüren kadınların oranının $\% 29,0$, donmuş etleri dışarıda bekleterek çözdüren kadınların oranının ise $\% 44,7$ olarak saptanması bizim çalışmamızla benzerdir.

Talas vd. [16]'nin çalışmasında, donmuş etleri tezgah üstünde çözdüren kadınların oranının $\% 39,6$, donmuş etleri buzdolabında çözdüren kadınların oranının \%40,4 olduğunun bulunması bizim çalışmamızla uyuşmamaktadır.

Cinsiyet ile "pişirmek üzere aldığınız donmuş et ürününü (kırmızı et, tavuk, balık, karides veya kalamarı) çözündürdünüz, ancak pişiremediniz, tekrar dondurur musunuz?" sorusuna verilen yanıtlar arasındaki farkın anlamlı $\left(p=0,039, \chi^{2}=4,245\right)$ olduğu saptanmıştır. Kadınların \%85,6'sı, erkeklerin $\% 79,5$ 'i doğru yanıt olan "hayır" seçeneğini işaretlemiştir $(p>0,05)$ (Tablo 7).

Karakuş ve Küçükkömürler [12]'in çalışmasında, çözündürülmüş etleri tekrar dondurucuya koyarak dondurmadıklarını ifade eden kadınlarının oranının \%77,3 olması bizim çalışmamızla uyuşmaktadır.

Cinsiyet ile "yemek hazırlığına başlamadan hemen önce elleri yıkamak neden önemlidir?" sorusuna verilen yanıtlar arasındaki farkın anlamlı $\left(p=0,018, \chi^{2}=10,114\right)$ olduğu bulunmuştur. Kadınların \%79,0, erkeklerin \%69,7'si doğru yanıt olan "ellerdeki mikroorganizmaların gıdalara bulaşmaması için" yanıtını işaretlemiştir (Tablo 7).

Cinsiyet ile "hangisi el yıkama işleminde kullanılan malzemedir?" sorusuna verilen yanttlar arasındaki farkın anlamlı olmadığ $1\left(p=0,165, \chi^{2}=5,091\right)$ tespit edilmiştir. Kadınların \%50,0'1, erkeklerin $\% 47,4$ 'ü doğru yanıt olan hepsi (tırnak firçası, sıcak su, dezenfektanlı el jeli) yanıtını vermiştir $(p<0,05)$ (Tablo 7).

Karakuş ve Küȩükkömürler [12]'in çalışmasında; yiyecek hazırlamadan önce ellerini mutlaka sicak sabunlu su ile ovarak yıkayan kadınların oranı $\% 85,7$ ve yiyecek hazırlama esnasında da ellerini sık sık sabunla yıkadığını belirten kadınların oranı \%84,7 olarak belirlenmiştir.

Cinsiyet ile "yıkanmış ellerin kurulanmasında aşağıdakilerden hangisini tercih edersiniz?" sorusuna verilen yanitlar arasındaki farkın anlamlı olmadığ $\left(p=0,317, \chi^{2}=2,297\right)$ bulunmuştur. Kadınların \%67,1'i, erkeklerin \%67,5'i doğru yanıt olan "kağıt havlu" seçeneğini işaretlemiştir (Tablo 7).

Karakuş ve Küçükkömürler [12]'in çalışmasında kadınların \%74,0'ünün mutfakta genellikle kağıt havlu kullanmayı tercih ettiğini belirtmesi bizim çalışmamızla uyuşmaktadır.

Cinsiyet ile "mutfakta yemek hazırlı̆̆ ve pişirmesi sırasında aşağıldakilerden hangilerini kullanırsınız?" sorusuna verilen yanıtlar arasındaki farkın anlamlı $\left(p=0,009, \chi^{2}=13,522\right)$ olduğu saptanmıştır. Kadınların \%34,5'i, erkeklerin \%36,8'i doğru yanıt olan "hepsi (mutfak önlüğü, eldiven, bone ya da tülbent)" yanıtını vermiştir (Tablo 7).

Karakuş ve Küçükkömürler [12]'in çalışmasında kadınların \%79,3'ü "mutfakta çalışırken saçlarımı toplar ya da bir bone vb. ile kapatırım" ifadesine katılmış, \%77,3'ü gıda hazırlarken mutfak önlüğü kullandığını belirtmiştir.

Talas vd. [16]'nin çalışmasında her zaman önlük takan kadınların oranı \%36,4, bazen önlük taktığını belirten kadınların oranı \%38,8 olarak tespit edilmiştir.

Cinsiyet ile "mutfakta yemek hazırlığı sırasında kullanılan araç, gereç, alet vb. temizliğini ne sıklıkla yaparsınız?" sorusuna verilen cevaplar arasındaki farkın anlamlı $\left(p=0,000, \chi^{2}=22,847\right)$ olduğu görülmüştür. Kadınların \%63,5’i bu sorunun doğru cevabı olan; "mutfakta yemek hazırlığ sırasında kullandıkları araç ve gereçleri kullandıktan hemen sonra sıcak su ve temizlik malzemeleriyle yıkarım" seçeneğini işaretlerken; erkeklerin sadece \%48,7'sinin bu seçeneği işaretlediği bulunmuştur (Tablo 7).

Cinsiyet ile "pişen et, tavuk ya da balığın iç sıcaklığı aşağıdaki şıklardan hangisi olmalıdır?" sorusuna verilen cevaplar arasındaki farkın anlamlı $\left(p=0,034, \chi^{2}=8,702\right)$ olduğu görülmüştür. Kadınların $\% 42,0$ ', erkeklerin $\& 50,4$ 'ü doğru yanıt olan “ $65-75^{\circ} \mathrm{C}$ ” yanıtını işaretlemiştir (Tablo 7). 
Cinsiyet ile "pişmiş yemekte lezzet kontrolü nasıl yapılmalıdır?" sorusuna verilen cevaplar arasındaki farkın anlamlı olmadı $\breve{g} 1\left(p=0,183, \chi^{2}=4,848\right)$ belirlenmiştir. Kadınların \%78,5'i, erkeklerin $\% 77,4$ 'ü doğru olan "temiz bir kaşıkla yemekten çok küçük bir miktar direkt ağıza veya bir kaba alınarak tadılır” yanıtını işaretlemiştir (Tablo 7).

Karakuş ve Küçükkömürler [12]'in çalışmasında; kadınların \%84,3'ünün yemeklerin tadına ayrı bir kaşıkla baktığını ifade etmesi bizim çalışmamızla uyuşmaktadır.

Cinsiyet ile "yeniden ssıtma işlemine tabi tutulacak et ve balık yemekleri en az kaç dereceye kadar 1sitılmalıdır?" sorusuna verilen cevaplar arasındaki farkın anlamlı $\left(p=0,016, \chi^{2}=12,180\right)$ olduğu saptanmıştır. Ancak, kadınların \%15,5'i, erkeklerin \%15,8'i doğru yanıt olan "70-75 ${ }^{\circ} \mathrm{C}$ " seçeneğini işaretlemiştir (Tablo 7).

Karakuş ve Küçükkömürler [12]'in çalışmasında ise; kadınların \%77,3'ü pişmiş yemekleri 1sıtırken kaynamasını beklediklerini ifade etmiştir.

\section{Sonuç ve Öneriler}

G1da güvenliği ve hijyen ile ilgili olarak en önemli olduğunu düşündüğümüz bilgi ve uygulamalar konusunda doğru bilgi ve alışkanlık sahibi olmanın eğitim seviyesinin artmasıyla doğru orantılı olmadığı gözlemlenmiştir. Lisansüstü mezunu katılımcıların düşünüldüğü gibi her soruya doğru cevabı vermediği, içlerinde yanlış bilgilere sahip katılımcıların da olduğu görülmüştür. Benzer şekilde; herkes tarafindan doğru yanıtlanan sorularda ilköğretim mezunu katılımcıların çoğunun cevabı doğru olmuştur.

Cinsiyet ile çoğu soruya verilen yanıtlar arasındaki farkın anlamlı olmadığı ve istatistiksel olarak anlamlı fark bulunan soruların yanıtlarının dağılımında kadın ve erkeklerin yüzdelik oranlarının oldukça yakın olduğu ve bazı sorulara her iki cinsin de yanlış cevap verdiği saptanmıştır. Bu sebeple, kadınların ve erkeklerin gida güvenliği ve hijyen ile ilgili bilgi ve tutumlarının genel anlamda benzer olduğu, ancak el yıkamanın önemi ve ekipman temizliği konularına kadınların daha hassasiyet gösterdiği anlaşılmıştır.

Anketlerin değerlendirilmesine göre; gıda güvenliği ve hijyen ile bilgilerin ilk öğrenildiği yerin çok önemli olduğu, daha sonra alışkanlık haline dönüştürülen yanlış bilgi ve uygulamaların değiştirilmesinin çok zor olduğu aşikardır.

Sağlıklı gıda tüketimi için vazgeçilmez olan gıda güvenliği, gıda hijyeni, el ve mutfak hijyeni konularına eğitim sisteminin her aşamasında yer verilmesinin dışında, eğitimini tamamlamış kişiler için bilgilendirici broşürler, afişler ve tanıtım filmleri toplumun bilgi seviyesini yükseltecek ve önemli bir önleyici faaliyet olarak karşımıza çıkacaktır. Doğru bilgi, doğru uygulama ancak eğitim ile mümkün olabilmektedir.

\section{Kaynaklar}

[1] Kayaard1 S. 2012. Gida Hijyeni ve Sanitasyon, Sidas, 252s. İzmir.

[2] Göktan D., Tunçel G. 2016. Temel Gıda Hijyeni, Sidas, 210s. İzmir.

[3] Kutluay Merdol T., Beyhan Y., Ciğerim N., Sağlam F., Tayfur M., Baş M., Dağ A. 2003. Toplu Beslenme Yapılan Kurumlarda Çalışan Personel İçin Sanitasyon/Hijyen Rehberi, Hatipoğlu Yayınlar1, 142s. Ankara.

[4] Tayar M., Kılıç V. 2014. Gıda Endüstrisinde Hijyen ve Sanitasyon, Dora Yayıncılık, 556s. Bursa.

[5] Askarian M., Kabir G., Aminbaig M., Memish Z., Jafari P. 2004. Knowledge, attitudes, and practices of food service staff regarding food hygienein Shiraz, Iran, Infection Control Hospital Epidemiology, 25: 16-20.

[6] McSwane D., Rue N.R., Linton R. 2005. Essentials of Food Safety and Sanitation, 5th ed, Pearson Prentic Hall, p.440. New Jersey.

[7] Koçoğlu G., Sümer H., Nur N., Polat H. 2002. Gıda maddesi üreten ve satan yerlerde çalışanların sanitasyon konusunda bilgi düzeyleri, Ulusal Halk Sağlığı Kongresi, Üçüncü Bölüm: Çevre Sağlı̆̆ı, 23-28 Eylül, Bildiri Kitabı, 392s. Diyarbakır.

[8] Uzunöz M., Büyükbay E.O., Bal H.S.G. 2008. Kırsal kadınların gıda güvenliği konusunda bilinç düzeyleri (Tokat ili örneği), Uludağ Üniversitesi Ziraat Fakültesi Dergisi, 22 (2): 35-46.

[9] Şanlıer N., Cömert M., Durlu-Özkaya F. 2010. Hygiene perception: condition of hotel kitchen staffs in Ankara, Turkey, Journal of Food Safety, 30 (2): 415-431. 
[10] Ünüsan N. 2007. Consumer food safety knowledge and practices in the home in Turkey, Food Control, 18 (1): 45-51.

[11] Memiş Kocaman E., Şanlıer N. 2014. Öğretmenlerin gıda güvenliği bilgi düzeylerinin tutumlarına etkisi, TAF Preventive Medicine Bulletin, 13 (2): 151-160.

[12] Karakuş S.Ş., Küçükkömürler S. 2012. Kadınların gıda güvenliğine yönelik uygulamaları, TAF Preventive Medicine Bulletin, 11 (6): 651-660.

[13] Sağlam F., Gümüş A., Dokcan B. 1999. Tüketicilerin gıda satın alımına ilişkin bilgi, tutum ve davranışları, Beslenme ve Diyet Dergisi, 28 (1): 39-46.

[14] Lynch R.A., Elledge B.L., Charles P.H., Griffith C.C., Boatright D.T. 2003. A comparison of food safety knowledge among restourant managers, by source of training and experience, in Oklahoma Country, Journal of Environmental Health, 66 (2): 9-14.

[15] Koçak H. 2005. Amasya ili merkez ilçesi ve köylerinde yiyecek hazırlama, pişirme ve saklama uygulamaları, Ankara Üniversitesi, Fen Bilimleri Enstitüsü, Ev Ekonomisi (Beslenme Bilimleri) Anabilim Dalı, Yüksek Lisans Tezi, 134s, Ankara.

[16] Talas C., Uçar A., Özçelik Ö.A. 2009. Women food safety practices from shopping to eating in Ankara, Turkey, Pakistan Journal of Nutrition, 8 (9): 1422-1429.

[17] Demirci A., Ersoy A.F. 2011. Gıda reyonunda çalışan personelin kişisel hijyen kurallarına dikkat etme durumlar1, NWSA Academy Journal, 6 (2): 2 C0035.

[18] Pragle A., Harding A., Mack C. 2007. Food workers perspectives on hand washing behaviors and barriers in the restourant environment, Journal of Environmental Health, 69: 27-32.

[19] Enç N., Atabek T., Acaroğlu R. 1994. Üniversite öğrencilerinin el yıkama alışkanlıkları ile ilgili bilgi düzeylerinin karşılaştırılması, Hemşirelik Bülteni, 8: 33.

[20] Çıkmaz N. 1997. Ankara Üniversitesi Tıp Fakültesi hastaneleri ve dekanlık mutfak, yemekhane çalışanlarının gıda hijyeni ile ilgili bilgi ve uygulamaları, Ankara Üniversitesi Tıp Fakültesi, Yüksek Lisans Tezi, $96 \mathrm{~s}$, Ankara.

[21] Clayton D., Griffith C. 2004. Observation of food safety practices in catering using notational analysis, British Food Journal, 106 (3): 211-227.

[22] Elmacıoğlu F. 1998. Samsun ili öğrenci yurtlarının mutfaklarında hijyen durumunun değerlendirilmesi, 1. Ulusal Kurum Ev İdaresi Kongresi, s. 363-370, 21-23 Ekim, Ankara.

[23] Green L., Radke V., Mason R., Bushnell L., Reimann D., Mack J., Motsinger M., Stigger T., Selman C. 2007. Factors related to food worker hand hygiene practices, Journal of Food Protection, 70 (3): 661-666.

[24] Ural D. 2007. Konaklama işletmelerinde çalışan personelin kişisel hijyen bilgileri ve uygulamaları üzerine bir araştırma, Gazi Üniversitesi, Eğitim Bilimleri Enstitüsü, Aile Ekonomisi ve Beslenme Eğitimi Anabilim Dalı, Yüksek Lisans Tezi, 96 s, Ankara.

[25] Alterkruse S.F., Street D.A., Fein S.B., Levy A.S. 1996. Consumer knowledge of foodborne microbial hazards and food-handling practices, Journal of Food Protection, 59 (3): 287-294.

[26] McSwane D.Z., Linton R., Rue N.R. 2007. Retail Best Practices and Guide to Safety Food and Sanitation, 2th ed., Prentice Hall, p.386. Washington.

[27] Şimşek I., Baykara T. 1986. İlaç imalatında personel hijyeni, Türk Hijyen ve Deneysel Biyoloji Dergisi, 43 (2): 103-112.

[28] Bilici S. 2008. Toplu Beslenme Sistemleri Çalışanları İçin Hijyen El Kitabı, Sağlık Bakanlığı Temel Sağl1k Hizmetleri Genel Müdürlüğ̈̈, 48s. Ankara.

[29] Ciğerim N., Beyhan Y. 1994. Toplu Beslenme Sistemlerinde Hijyen, 1. Baskı, Kök Yayıncılık, Ankara.

[30] Scott E., Bloomfield S.F. 1990. The survival and transfer of microbial contamination via cloths, hands and utensils, Journal of Applied Microbiology, 68 (3): 271-278.

[31] Byrd-Bredbenner C., Moe G., Beshgetoor D., Berning J. 2012. Wardlaw's Perspectives in Nutrition, 9th ed., Mc Graw Hill Education, p.976. Boston.

[32] Bilici S., Uyar M.F., Beyhan Y., Sağlam F. 2008. Besin Güvenliği, Beslenme Bilgi Serisi, 1. Bask1, Ankara: Sağlık Bakanlığı Yayınları, 347-356.

[33] De Jong A.E., Verhoeff-Bakkenes L., Nauta M.J., de Jonge R. 2008. Cross contamination in the kitchen: effect of hygiene measures, Journal of Applied Microbiology, 105 (2): 615-624. 
[34] Howes M., McEwen S., Griffiths M., Haris L. 1996. Food handler certification by home study: measuring changes in knowledge and behaviour, Dairy, Food and Environmental Sanitation, 16: 737-744.

[35] Sneed J., Strohbehn C., Gilmore S.A., Mendonca A. 2004. Microbiological evaluation of food service contact surfaces in Iowa assisted-living facilities, Journal of Food Protection, 1722: 4.

[36] Duyff R.L. 1998. The American Dietetic Association Complete Food \& Nutrition Guide, 4th ed., Chronimed Publishing, p.673. New York.

[37] Worsfold D., Griffith C.J. 1997. Assessment of the standard of consumer food safety behavior, Journal of Food Protection, 60 (4): 399-406.

[38] Fischer A.R.H., de Jong A.E., van Asselt E.D., de Jonge R., Frewer L.J., Nauta M.J. 2007. Food safety in the domestic environment: an interdisciplinary investigation of microbial hazards during food preparation, Risk Analysis, 27 (4): 1065-1082.

[39] Worsfold D., Griffith C.J. 2003. A survey of food hygiene and safety training in the retail and catering industry, Nutrition \& Food Science, 33 (2): 68-79.

[40] Clayton D.A. 2002. Food handlers' beliefs and self-reported practices, International Journal of Environmental Health Research, 12 (1): 25-39. 